\title{
Pollution status of microplastics in the freshwater environment of China: a mini review
}

\author{
Haoran Zhao', Yanting Zhou', Ye Han', Yue Sun', Xiuna Ren', Zengqiang Zhang1, Quan Wang ${ }^{1,2}$ \\ ${ }^{1}$ College of Natural Resources and Environment, Northwest A\&F University, Yangling 712100, Shaanxi, China. \\ ${ }^{2}$ Key Laboratory of Plant Nutrition and the Agrienvironment in Northwest China, Ministry of Agriculture, Yangling 712100, \\ Shaanxi, China.
}

Correspondence to: Dr. Quan Wang, College of Natural Resources and Environment, Northwest A\&F University, No.3 Taicheng Road, Yangling 712100, Shaanxi, China. E-mail: quanwang_1990@163.com

How to cite this article: Zhao H, Zhou Y, Han Y, Sun Y, Ren X, Zhang Z, Wang Q. Pollution status of microplastics in the freshwater environment of China: a mini review. Water Emerg Contam Nanoplastics 2022;1:5.

https://dx.doi.org/10.20517/wecn.2021.05

Received: 27 Dec 2021 First Decision: 20 Jan 2022 Revised: 10 Feb 2022 Accepted: 22 Feb 2022 Published: 1 Mar 2022

Academic Editor: Antonio Ginebreda Copy Editor: Xi-Jun Chen Production Editor: Xi-Jun Chen

\begin{abstract}
In the last few years, the pollution of microplastics in freshwater environments such as rivers, lakes, and reservoirs has aroused widespread concerns. In this review, rich and appropriate data on microplastics, in the freshwater ecosystem of China, was collected. Following this microplastics in surface waters, sediments, and biota, of the freshwater system, were thoroughly analyzed. The results show that microplastics are widespread in the freshwater environment of China. At the same time, the abundance of microplastics is positively correlated with both intensive human activities and urbanization. The risk index of microplastics is relatively high in the water of Yellow River (654 items/L), Yangtze River $\left(9.20 \times 10^{5}\right.$ items $\left./ \mathrm{km}^{2}\right)$, and Pearl River regions $\left(7571 \mathrm{items} / \mathrm{m}^{3}\right)$. The prevalent shapes of microplastics, in water and sediments, are fragments and fibers. Moreover, the particle size of microplastics is mainly less than $2 \mathrm{~mm}$. In fact, PP and PE are found to be the main polymer types in the freshwater environment of China. Bivalves and freshwater fish are the main research objects of microplastics pollution in China. In parallel to that, the abundance of microplastics, in each aquatic organism, varied from a few to a dozen. Additionally, the characteristics of microplastics in organisms are mainly fibers smaller than $1 \mathrm{~mm}$. Fundamentally, the key two sources of microplastics, in the freshwater environment of China, are wastewater discharge and surface runoff. It is noteworthy that microplastics, in a freshwater environment, does not only cause environmental pollution but harms aquatic organisms, too. Finally, microplastics can reach the human body, through the food chain, causing potential health issues.
\end{abstract}


Keywords: Microplastics, freshwater, China, source, biota

\section{INTRODUCTION}

Plastic has been widely used in industry due to its unique properties such as low price, lightweight, high strength, and durability ${ }^{[1]}$. Since the 1950 s, more than 8.3 billion metric tons of plastic have been manufactured, which makes it world-recognized garbage and pollutant. Statistically, the global plastic production was 368 million tons in 2019, and China occupied $31 \%$ of the total production ${ }^{[2]}$. Every year, more than 8 million tons of plastic waste enter the freshwater and marine environment worldwide ${ }^{[3]}$.

Large pieces of plastic would break down into microplastics which are emerging pollutants. Microplastics, defined as plastic debris with a particle size of less than $5 \mathrm{~mm}$, can be divided into primary and secondary microplastics according to the origin of microplastics ${ }^{[4]}$. Basically, primary microplastics are manufactured into small-size plastics (e.g., microbeads, plastic pellets, and microfibers), while secondary microplastics are originated from large plastics through physical, chemical, and biological degradation ${ }^{[5]}$. Microplastics, as a global pollutant, are widely presented in aquatic, terrestrial, and atmospheric ecosystems, even they were discovered in remote Antarctic and Arctic regions ${ }^{[6,7]}$. Meanwhile, the microplastics that were detected in the environment include various types [e.g., polypropylene (PP), polyethylene (PE), polystyrene (PS), polyvinyl chloride (PVC), and polyethylene terephthalate (PET)], shapes (e.g., fiber, fragment, pellet, film, and foam), and colors (e.g., black, colored, and white $)^{[4,8]}$.

Microplastics have a large specific surface area and hydrophobic properties, therefore can adsorb persistent organic pollutants (e.g., PCBs, PAHs, and PBDEs) and heavy metals, enhancing their transportation in terrestrial and aquatic ecosystems ${ }^{[9]}$. Recently, many studies have studied microplastic pollution in aquatic ecosystems. Microplastics are easily ingested by aquatic organisms like zooplankton, fish, and bivalves causing a decreased reproduction rate, mechanical injuries, and low growth rate of these aquatic $\operatorname{organism}^{[10]}$. Moreover, plasticizers or toxic additives, released from microplastics, are transferred to water, sediments, and biota which aggravate the pollution of the freshwater environment ${ }^{[9]}$. Meanwhile, microplastics carrying toxic pollutants may be transferred to higher nutritional levels, through the food chain, reaching the human body and causing various health issues ${ }^{[11]}$.

The majority of early microplastics research focused on their abundance and pollution in the marine environment, including seawater, seabed sediments, and marine biota ${ }^{[12]}$. Unlike the ocean, freshwater (e.g., river, lake, and reservoir) is a vital resource for human life. Simultaneously, it is essential for human reproduction providing drinking water source, food production water, permitting freshwater aquaculture, and playing an important role in sanitation, purification, and stabilization of the coastline $\mathrm{e}^{[13]}$. Consequently, more researchers gradually started to investigate the microplastic pollution in the freshwater ecosystem in developed and developing countries. For example, Eriksen et al. ${ }^{[14]}$ (2013) showed that the average abundance of microplastics was approximately 43,000 particles $/ \mathrm{km}^{2}$ in the surface water of the Laurentian Great Lakes in the United States. At the same time, He et al.$^{[15]}$ (2020) demonstrated that the microplastics varied between 0.18 and $129.20 \mathrm{mg} \mathrm{kg}^{-1}$ in Brisbane River sediments, Australia. Similarly, Buwono et al. ${ }^{[16]}$ (2021) found that the abundance of microplastics, in the water of the Brantas River in Indonesia, ranged from 133 to 5467 particles $/ \mathrm{m}^{3}$.

Obviously, China, as one of the largest countries, are regarded as the largest plastic producer and consumer in the world ${ }^{[10]}$. Every year, a huge number of microplastics enters the freshwater environment of China through surface runoff, rainfall, and sewage discharge, causing serious microplastics pollution in surface 
water, sediments, and biota of the freshwater environment ${ }^{[5,17,18]}$. Hence, there have been progressively more studies investigating the distribution and abundance of microplastics in the freshwater environment (e.g., water, sediments, and biota) of China in the recent years ${ }^{[5,8,19]}$. For example, Huang et al. ${ }^{[19]}(2020)$ and Pan et al. ${ }^{[20]}$ (2020) clearly described the abundance, shape, chemical composition, and size distribution of microplastics in the Zhangjiang River and West River. Wang et al. ${ }^{[5]}$ (2020) not only evaluated the microplastics in Beijiang surface water but also detected microplastics in fish samples. In parallel to that, Li et al. ${ }^{[2]}$ (2021) and Mao et al. ${ }^{[22]}$ (2020) studied microplastic pollution in both the Yulin River and Chishui River.

Thus far, the microplastics pollution in the freshwater environment has attracted a great attention. Although, the current research generally focuses on the abundance, sources, and characteristics of microplastics in rivers and lakes in a single region. It ignores the freshwater environment, especially the microplastics pollution in China, which is not conducive to follow-up research and policy research for controlling the microplastic pollution. Hence, the main purpose of this review is twofold: (1) to summarize the abundance and characteristics of microplastics in freshwater environments (e.g., rivers, lakes, sediments, and biota) of China; and (2) to introduce the source and impact of microplastics in freshwater ecosystems of China.

\section{DATA COLLECTION}

Since 2017, the issue of microplastics, in the freshwater environment of China, has gradually attracted more attention. Hence, this review focuses on the research papers that were published between 2017 and 2021. Several combination of keywords such as "microplastics", "freshwater", "China", "lakes", and "rivers" were used to initiate search queries for the articles in the database of Web of Science and Science Direct. Following this procedure, 62 articles were initially selected. In this review, we mainly focus on the major freshwater environments of China including rivers, lakes, and reservoirs which are closely related to human community. After the final screening, based on the distribution of major rivers, lakes and reservoirs in China, a total of 29 (water $=24$, sediment $=13$, and biota $=11)$ research articles were carefully chosen.

\section{MICROPLASTIC POLLUTION IN THE FRESHWATER OF CHINA}

In the last few years, risk assessment of microplastic, in the freshwater environment of China, has become a hotspot. We counted 29 studies to analyze the presence of microplastics in freshwater, sediments, and biota. Moreover, the following attributes such as the abundance, size, shape, type, and identification of microplastics were also described in Tables 1-3.

\section{Water}

The location of the study water samples is shown in Figure 1. The existing literature, about the microplastic pollution in the freshwater of China reveals that trawl nets, pumps, and water collectors were the main sampling methods for collecting the microplastics as indicated in Table 1. On the other hand, these dissimilar sampling methods led to the variances in the expression of microplastic abundance. For surface water of river or lake sampled by trawl, noting that the commonly used unit is "items $/ \mathrm{km}^{2}$ ". By contrast, the

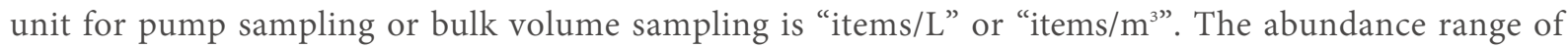
microplastics in Chinese freshwater (e.g., river, lake, and reservoir) is $0.03 \times 10^{5}-81.2 \times 10^{5} \mathrm{items} / \mathrm{km}^{2}$ in the trawl samples as can be seen from Table 1. According to the volume sampling method, the abundance range of microplastics in Chinese freshwater is 16.67 to $24798 \mathrm{items} / \mathrm{m}^{3}$ and 1.7 to 1392 items/L as detailed in Table 1. The expression methods of different units may not be conducive to the subsequent evaluation and research of microplastics. For a better evaluation, it is recommended to unify the units of measure in future research. Although the sampling methods are different, the main shapes of the microplastics in the 
Table 1. The abundance and characteristics of microplastics in water

\begin{tabular}{|c|c|c|c|c|c|c|c|c|c|}
\hline Water & Location & $\begin{array}{l}\text { Abundance } \\
\text { (average) }\end{array}$ & Size & Sampling & Shape & Color & Polymer types & Identification & Ref. \\
\hline & Beijiang River & $\begin{array}{l}400-8400 \text { items } / \mathrm{m}^{3} \\
\left(3183 \text { items } / \mathrm{m}^{3}\right)\end{array}$ & $\begin{array}{l}<0.5 \mathrm{~mm} \\
(77 \%)\end{array}$ & Trap & - & $\begin{array}{l}\text { White (49\%), yellow }(16 \%) \text {, blue } \\
(10 \%) \text {, black }(9 \%) \text {, red }(8 \%) \text {, green } \\
(8 \%)\end{array}$ & - & Microscope & {$[5]$} \\
\hline & The Pearl River & $\begin{array}{l}2400-18200 \\
\text { items } / \mathrm{m}^{3} \\
\left(7571 \text { items } / \mathrm{m}^{3}\right)\end{array}$ & $\begin{array}{l}<0.5 \mathrm{~mm} \\
(86 \%) \\
2-4 \mathrm{~mm}(3 \%)\end{array}$ & Trap & $\begin{array}{l}\text { Fragment (67\%), Fiber (21\%), film } \\
(3 \%) \text {, spheres (9\%) }\end{array}$ & $\begin{array}{l}\text { White ( } 49 \%) \text {, yellow }(16 \%) \text {, blue } \\
(10 \%) \text {, black }(9 \%) \text {, red }(8 \%) \text {, green } \\
(8 \%)\end{array}$ & & Microscope & \\
\hline & $\begin{array}{l}\text { Dafeng River } \\
\text { (rainy season) }\end{array}$ & $\begin{array}{l}3 \times 10^{-4}-2.5 \times 10^{-3} \\
\text { items } / L \\
7 \times 10^{-4}-0.12 \\
\text { items } / \mathrm{m}^{2}\end{array}$ & $\begin{array}{l}1-5 \mathrm{~mm} \\
\text { (dominant) }\end{array}$ & Trawl net & Fiber (dominant) & - & PET (dominant) & Microscope; FTIR & {$[8]$} \\
\hline & $\begin{array}{l}\text { Dafeng River } \\
\text { (dry season) }\end{array}$ & $\begin{array}{l}4 \times 10^{-5}-9 \times 10^{-4} \\
\text { items } / L \\
2 \times 10^{-3}-2.8 \times 10^{-2} \\
\text { items } / \mathrm{m}^{2}\end{array}$ & & Trawl net & & & & Microscope; FTIR & \\
\hline & $\begin{array}{l}\text { West River } \\
\text { (lower) }\end{array}$ & 2.99-9.87 items/L & $\begin{array}{l}<0.5 \mathrm{~mm} \\
\text { (dominant) }\end{array}$ & $\begin{array}{l}\text { Stainless steel } \\
\text { drum }\end{array}$ & $\begin{array}{l}\text { Fiber (dominant), pellet, fragment } \\
\text { and film }\end{array}$ & - & $\begin{array}{l}\text { PP ( } 40 \%), \text { PE (29\%), PS } \\
(20 \%)\end{array}$ & Microscope; FTIR & {$[19]$} \\
\hline & $\begin{array}{l}\text { Zhangjiang } \\
\text { River }\end{array}$ & $\begin{array}{l}50-725 \text { items } / \mathrm{m}^{3} \\
\left(246 \text { items } / \mathrm{m}^{3}\right)\end{array}$ & $\begin{array}{l}0.3-0.5 \mathrm{~mm} \\
(20.6 \%) \\
0.5-1 \mathrm{~mm} \\
(32.8 \%) \\
1-2.5 \mathrm{~mm} \\
(31 \%) \\
2.5-5 \mathrm{~mm} \\
(15.7)\end{array}$ & Steel bucket & $\begin{array}{l}\text { Fragment ( } 42.9 \%) \text {, fiber }(18.5 \%) \text {, } \\
\text { pellet }(17.6 \%) \text {, line }(13.8 \%) \text {, film } \\
(4.1 \%) \text {, and foam }(3.1 \%) \text {. }\end{array}$ & $\begin{array}{l}\text { White }(55.5 \%) \text {, black }(14.4 \%) \text {, yellow } \\
(14.0 \%) \text {, grey }(6.2 \%) \text {, clear }(5.3 \%) \text {, and } \\
\text { blue }(3.4 \%)\end{array}$ & $\begin{array}{l}\text { PP }(51.7 \%), \text { PE ( } 23.1 \%) \\
\text { PE-PP }(7.0 \%), \text { PES } \\
(6.7 \%), \text { PS }(6.1 \%), \text { PET } \\
(5.3 \%)\end{array}$ & Microscope; Raman & [20] \\
\hline & Chishui River & $1.77-14.33$ items/L & $\begin{array}{l}500-1000 \\
\mu \mathrm{m}(63.9 \%)\end{array}$ & $\begin{array}{l}\text { Stainless-steel } \\
\text { bucket }\end{array}$ & Fiber (59.4\%) & $\begin{array}{l}\text { White (including transparent) (41.3\%) } \\
\text { and polychromatic (44.1\%) }\end{array}$ & $\begin{array}{l}\text { PE ( } 36 \%), \operatorname{PP}(31 \%), \text { PS } \\
(25 \%), \operatorname{PVC}(2 \%)\end{array}$ & Microscope; FTIR & [21] \\
\hline & Yulin River & $\begin{array}{l}0.70 \times 10^{-2}-1.70 \times \\
10^{-2} \text { items } / \mathrm{L} \\
\left(1.3 \times 10^{-2} \text { items } / \mathrm{L}\right)\end{array}$ & $\begin{array}{l}<250 \mu \mathrm{m} \\
\text { (dominant) }\end{array}$ & Teflon pump & Line/fiber, pellet/foam (dominant) & - & $\begin{array}{l}\text { PE (39\%), PP (31\%), PS } \\
(23 \%)\end{array}$ & $\begin{array}{l}\text { Microscope; SEM; } \\
\text { Raman }\end{array}$ & {$[22]$} \\
\hline & $\begin{array}{l}\text { Minjiang River } \\
\text { (Chengdu) }\end{array}$ & $\begin{array}{l}6.11-44.08 \text { items } / L \\
(15.88 \pm 3.13 \\
\text { items } / L)\end{array}$ & $\begin{array}{l}<300 \mu \mathrm{m} \\
(44.1 \%) \\
300-1000 \\
\mu \mathrm{m}(46.55) \\
>1000 \mu \mathrm{m} \\
(9.5 \%)\end{array}$ & Iron drum & $\begin{array}{l}\text { Particle }(10.3 \%) \\
\text { fragment }(44.8 \%) \text {, fiber }(44.9 \%)\end{array}$ & - & $\begin{array}{l}\text { PP ( } 26 \%), P E(15 \%), R A \\
(20 \%), P A, P S, P P-P E \\
\text { PVC }\end{array}$ & Microscope; FTIR & {$[23]$} \\
\hline & $\begin{array}{l}\text { Taihu Lake } \\
\text { (lake water) }\end{array}$ & $\begin{array}{l}1.7-8.5 \text { items } / \mathrm{L} \\
(5.67 \pm 1.92 \text { items } / \mathrm{L})\end{array}$ & $\begin{array}{l}<0.1 \mathrm{~mm} \\
(28 \%) \\
0.1-0.2 \mathrm{~mm} \\
(42 \%)\end{array}$ & Pump & $\begin{array}{l}\text { Fragment (58\%), fiber ( } 25 \%) \text {, film } \\
(12 \%) \text {, pellet (4\%) and piece }\end{array}$ & - & $\begin{array}{l}\text { PVC and PE (dominant), } \\
\text { PS, PP }\end{array}$ & $\begin{array}{l}\text { Microscope; FTIR; } \\
\text { SEM }\end{array}$ & [24] \\
\hline & Taihu Lake & $(6.31 \pm 4.36$ items $/ \mathrm{L}$ & $<0.1 \mathrm{~mm}$ & Pump & Fragment (58\%), fiber (25\%), film & & PVC and PE (dominant), & Microscope; FTIR; & \\
\hline
\end{tabular}




\begin{tabular}{|c|c|c|c|c|c|c|c|c|}
\hline (river water) & $\begin{array}{l}\text { inflow) } \\
(4.05 \pm 1.06 \text { items } / L \\
\text { outflow) }\end{array}$ & $\begin{array}{l}(28 \%) \\
0.1-0.2 \mathrm{~mm} \\
(42 \%)\end{array}$ & & $(12 \%)$, pellet (4\%) and piece & & PS, PP & SEM & \\
\hline \multirow[t]{2}{*}{ Yangtze River } & $\begin{array}{l}(1.62 \pm 0.61) \times 10^{5} \\
(4.25 \pm 3.87) \times 10^{6} \\
\text { items } / \mathrm{km}^{2} \\
\left(9.20 \times 10^{5}\right. \\
\left.\text { items } / \mathrm{km}^{2}\right)\end{array}$ & $\begin{array}{l}300 \mu \mathrm{m}-1 \\
\mathrm{~mm}(69.6 \%) \\
1-2.8 \mathrm{~mm} \\
(19.8 \%) \\
2.8-5 \mathrm{~mm} \\
(10.6 \%) .\end{array}$ & $\begin{array}{l}\text { Trawling } \\
\text { sample }\end{array}$ & $\begin{array}{l}\text { Fragment }(47.9 \%) \text {, fiber }(32.1 \%) \text {, } \\
\text { foam }(17.4 \%) \text {, pellet }(2.6 \%)\end{array}$ & $\begin{array}{l}\text { Transparent }(36.1 \%) \text {, white }(34.6 \%) \text {, } \\
\text { red }(6.6 \%) \text {, blue }(6.3 \%) \text {, yellow }(5.4 \%) \text {, } \\
\text { green }(4.9 \%) \text {, black }(0.9 \%) \text { and others } \\
(5.2 \%)\end{array}$ & $\begin{array}{l}\text { PP ( } 43 \%), \text { PE (29\%), PS } \\
(14 \%)\end{array}$ & Microscope; FTIR & [25] \\
\hline & $\begin{array}{l}(800.0 \pm 300.0)- \\
(3088.9 \pm 330.6) \\
\text { items } / \mathrm{m}^{3} \\
\left(1635 \text { items } / \mathrm{m}^{3}\right)\end{array}$ & $\begin{array}{l}<0.5 \mathrm{~mm} \\
(47.4 \%) \\
0.5-1 \mathrm{~mm} \\
(27.5 \%) \\
1-2 \mathrm{~mm} \\
(9.0 \%) \\
2-3 \mathrm{~mm} \\
(8.3 \%) \\
3-4 \mathrm{~mm} \\
(4.9 \%) \\
4-5 \mathrm{~mm} \\
(2.9 \%)\end{array}$ & $\begin{array}{l}\text { Stainless steel } \\
\text { bucket }\end{array}$ & $\begin{array}{l}\text { Fiber }(63.4 \%) \text {, fragment }(29.4 \%) \text {, } \\
\text { pellet }(4.6 \%) \text {, foam }(2.6 \%)\end{array}$ & $\begin{array}{l}\text { Transparent }(21.5 \%) \text {, blue }(15.4 \%) \text {, } \\
\text { green }(14.8 \%), \text { red }(13.9 \%) \text {, white } \\
(13.4 \%) \text {, yellow }(8.0 \%) \text {, black }(1.9 \%) \\
\text { and others }(11.0 \%)\end{array}$ & $\begin{array}{l}\text { PP (54.8\%), PE (35.5\%), } \\
\text { PS (3.2\%) }\end{array}$ & Microscope; FTIR & \\
\hline $\begin{array}{l}\text { Yellow River } \\
\text { (lower) }\end{array}$ & $\begin{array}{l}380-582 \text { items/L } \\
\text { (wet) } \\
(430 \text { items/L) } \\
623-1392 \text { items/L } \\
\text { (dry) } \\
(654 \text { items/L) }\end{array}$ & $\begin{array}{l}<200 \mu \mathrm{m} \\
(87.9 \%)\end{array}$ & $\begin{array}{l}\text { Stainless steel } \\
\text { bucket }\end{array}$ & $\begin{array}{l}\text { Fiber, fragment particles } \\
\text { (dominant) }\end{array}$ & - & $P P, P E, P S$ & Microscope; FTIR & {$[26]$} \\
\hline Qiantang River & $\begin{array}{l}50-3233 \text { items } / \mathrm{m}^{3} \\
(\text { dry) } \\
\left(1607 \text { items } / \mathrm{m}^{3}\right) \\
221-6517 \text { items } / \mathrm{m}^{3} \\
\text { (wet) } \\
\left(889 \text { items } / \mathrm{m}^{3} \text { ) }\right.\end{array}$ & $<5 \mathrm{~mm}$ & $\begin{array}{l}\text { Stainless steel } \\
\text { bucket }\end{array}$ & $\begin{array}{l}\text { Fiber }(53.2 \%) \text {, fragment }(29.5 \%) \text {, } \\
\text { granule }(8.4 \%) \text {, film }(8.5 \%) \text {, foam } \\
(0.4 \%)\end{array}$ & $\begin{array}{l}\text { White ( } 45 \%) \text {, black (23.4\%), } \\
\text { transparent }(14.6 \%)\end{array}$ & PET, PA, PES (dominant) & Microscope; FTIR & [27] \\
\hline $\begin{array}{l}\text { Qinghai-Tibet } \\
\text { Plateau }\end{array}$ & $247-2686$ items $/ \mathrm{m}^{3}$ & $20 \mu \mathrm{m}-5 \mathrm{~mm}$ & $\begin{array}{l}\text { Water } \\
\text { collector }\end{array}$ & - & - & - & Microscope; Raman & [30] \\
\hline Poyang Lake & $\begin{array}{l}(289 \pm 40-1064 \pm \\
\left.90 \text { items } / \mathrm{m}^{3}\right)\end{array}$ & $\begin{array}{l}<2 \mathrm{~mm} \\
\text { (dominant) }\end{array}$ & $\begin{array}{l}\text { Stainless-steel } \\
\text { bucket }\end{array}$ & $\begin{array}{l}\text { Fiber (dominant), film, foam, } \\
\text { fragment }\end{array}$ & - & PP, PVC, PE, PS & $\begin{array}{l}\text { Microscope; FTIR; } \\
\text { SEM }\end{array}$ & [31] \\
\hline $\begin{array}{l}\text { Qinghai Lake } \\
\text { (lake water) }\end{array}$ & $\begin{array}{l}0.05 \times 10^{5}-7.58 \times \\
10^{5} \text { items } / \mathrm{km}^{2}\end{array}$ & $\begin{array}{l}0.1-0.5 \mathrm{~mm} \\
\text { (dominant) }\end{array}$ & Trawl net & $\begin{array}{l}\text { Fiber and sheet (dominant), } \\
\text { fragment, foam }\end{array}$ & - & $\begin{array}{l}\text { PP and PE (dominant), } \\
\text { PS, PET }\end{array}$ & Microscope; Raman & [32] \\
\hline $\begin{array}{l}\text { Qinghai Lake } \\
\text { (river water) }\end{array}$ & $\begin{array}{l}0.03 \times 10^{5}-0.31 \times \\
10^{5} \text { items } / \mathrm{km}^{2}\end{array}$ & $\begin{array}{l}0.1-0.5 \mathrm{~mm} \\
\text { (dominant) }\end{array}$ & Trawl net & & & & & \\
\hline Dongting Lake & $\begin{array}{l}900-2800 \text { items } / \mathrm{m}^{3} \\
\left(1191.7 \text { items } / \mathrm{m}^{3}\right)\end{array}$ & $\begin{array}{l}<2 \mathrm{~mm} \\
\text { (dominant) }\end{array}$ & Teflon pump & Fiber (dominant), granule, film & Colored $(71.3 \%)$, transparent $(28.7 \%)$ & $\begin{array}{l}\text { PP and PE (dominant), } \\
\text { PS, PVC }\end{array}$ & $\begin{array}{l}\text { Microscope; SEM; } \\
\text { Raman }\end{array}$ & [33] \\
\hline
\end{tabular}




\begin{tabular}{|c|c|c|c|c|c|c|c|c|}
\hline & $\left(2282.5\right.$ items $\left./ \mathrm{m}^{3}\right)$ & & & & & & & \\
\hline $\begin{array}{l}\text { Danjiangkou } \\
\text { Reservoir }\end{array}$ & $\begin{array}{l}530-24798 \\
\text { items } / \mathrm{m}^{3} \\
\left(7205 \text { items } / \mathrm{m}^{3}\right)\end{array}$ & $\begin{array}{l}75-200 \mu \mathrm{m} \\
(10 \%) \\
200-500 \mu \mathrm{m} \\
(61.4 \%) \\
500-1000 \\
\mu \mathrm{m}(20.7 \%) \\
1000-5000 \\
\mu \mathrm{m}(7.9 \%)\end{array}$ & $\begin{array}{l}\text { Stainless-steel } \\
\text { water sampler }\end{array}$ & $\begin{array}{l}\text { Fragment (dominant), fiber, film, } \\
\text { pellet, microbead }\end{array}$ & $\begin{array}{l}\text { Transparent (42.8\%), brown ( } 40.9 \%) \text {, } \\
\text { black }(5.9 \%) \text {, green }(3.7 \%) \text {, gray }(3.3 \%)\end{array}$ & $\begin{array}{l}\text { PA (24.8\%), PE (24\%), } \\
\operatorname{PP}(17.1 \%)\end{array}$ & Microscope; Raman & {$[36]$} \\
\hline $\begin{array}{l}\text { Three Gorges } \\
\text { Reservoir }\end{array}$ & $\begin{array}{l}1597-12611 \text { items } / \mathrm{m}^{3} \\
(4703 \pm 2816 \\
\left.\text { items } / \mathrm{m}^{3}\right)\end{array}$ & $\begin{array}{l}<0.5 \mathrm{~mm} \\
\text { (dominant) }\end{array}$ & Teflon pump & $\begin{array}{l}\text { Fiber (dominant), fragment, pellet, } \\
\text { film, and Styrofoam }\end{array}$ & Transparent (dominant) & $\begin{array}{l}\text { PS ( } 38.5 \%), \text { PP (29.4\%), } \\
\text { PE (21\%), PC, PVC }\end{array}$ & $\begin{array}{l}\text { Microscope; } \\
\text { Raman; SEM }\end{array}$ & [37] \\
\hline \multirow[t]{3}{*}{$\begin{array}{l}\text { Qin River } \\
\text { (lower) }\end{array}$} & $\begin{array}{l}16.67-611.11 \\
\text { items } / \mathrm{m}^{3}\end{array}$ & $\begin{array}{l}1-5 \mathrm{~mm} \\
(80.3 \%)\end{array}$ & Teflon pump & Fiber $(88 \%)$, sheet and fragment & White, black, green, and blue(dominant) & \multirow[t]{3}{*}{$\begin{array}{l}\text { PP (39\%), PE (28\%), } \\
\text { PET, PS }\end{array}$} & \multirow[t]{3}{*}{ Microscope; FTIR } & \multirow[t]{3}{*}{ [79] } \\
\hline & $0.1-5.6$ items $/ \mathrm{m}^{3}$ & $\begin{array}{l}1-5 \mathrm{~mm} \\
(84.4 \%)\end{array}$ & $\begin{array}{l}75 \mu \mathrm{m} \\
\text { plankton nets }\end{array}$ & $\begin{array}{l}\text { Fiber }(49.6 \%) \text {, line, sheet, } \\
\text { fragment, and foam }\end{array}$ & White, black, green, and blue(dominant) & & & \\
\hline & $0.1-4.6$ items $/ \mathrm{m}^{3}$ & $\begin{array}{l}1-5 \mathrm{~mm} \\
(88.9 \%)\end{array}$ & $\begin{array}{l}300 \mu \mathrm{m} \\
\text { plankton nets }\end{array}$ & $\begin{array}{l}\text { Fiber }(38.2 \%) \text {, line, sheet, } \\
\text { fragment, and foam }\end{array}$ & $\begin{array}{l}\text { White, black, green, and blue } \\
\text { (dominant) }\end{array}$ & & & \\
\hline \multirow[t]{3}{*}{ Lijiang River } & $\begin{array}{l}(67.5 \pm 65.6 \\
\left.\text { items } / \mathrm{m}^{3}\right)\end{array}$ & $\begin{array}{l}0.3-1 \mathrm{~mm} \\
\text { (dominant) }\end{array}$ & Teflon pump & Flake and fiber (dominant), film & Blue, red, green, and white (dominant) & \multirow{3}{*}{$\begin{array}{l}\text { PP/PE (37.6\%), PE } \\
(32.2 \%), P P(19.1 \%), \\
\text { PVC, PS, PET, PA, PES }\end{array}$} & \multirow[t]{3}{*}{ Microscope; FTIR } & \multirow[t]{3}{*}{ [80] } \\
\hline & $\begin{array}{l}(0.15 \pm 0.15 \\
\left.\text { items } / \mathrm{m}^{3}\right)\end{array}$ & $\begin{array}{l}1-5 \mathrm{~mm} \\
\text { (dominant) }\end{array}$ & $\begin{array}{l}75 \mu \mathrm{m} \\
\text { plankton net }\end{array}$ & $\begin{array}{l}\text { Flake and fiber (dominant), film, } \\
\text { granule, line, string, and foam }\end{array}$ & Blue, red, green, and white (dominant) & & & \\
\hline & $\begin{array}{l}(0.67 \pm 0.41 \\
\left.\text { items } / \mathrm{m}^{3}\right)\end{array}$ & $\begin{array}{l}1-5 \mathrm{~mm} \\
\text { (dominant) }\end{array}$ & $\begin{array}{l}300 \mu \mathrm{m} \\
\text { plankton net }\end{array}$ & $\begin{array}{l}\text { Flake and fiber (dominant), film, } \\
\text { granule, line, string, and foam }\end{array}$ & Blue, red, green, and white (dominant) & & & \\
\hline Wei River & 3.67-10.7 items/L & $\begin{array}{l}<0.5 \mathrm{~mm} \\
\text { (dominant) }\end{array}$ & Pump & Fiber and film (dominant) & - & - & Microscope; SEM & [81] \\
\hline Tuojiang River & $\begin{array}{l}911.57 \pm 199.73- \\
3395.27 \pm 707.22 \\
\text { items } / \mathrm{m}^{3}\end{array}$ & $\begin{array}{l}0.5-1 \mathrm{~mm} \\
\text { (dominant) }\end{array}$ & Steel sampler & $\begin{array}{l}\text { Fiber (dominant), film, fragment, } \\
\text { foam }\end{array}$ & White and multicolor (dominant) & $\begin{array}{l}\text { PP (34\%), PE (29\%), PS } \\
(23 \%)\end{array}$ & Microscope; FTIR & {$[82]$} \\
\hline
\end{tabular}

freshwater of China are similar, mostly fibers and fragments that account for more than $60 \%$ of the total microplastics. The main source of fiber and fragments is the decomposition of plastic containers such as plastic bags, fishing nets, and lines ${ }^{[22-24}$. At the same time, the size of most of the microplastics, in the freshwater of China, is smaller than $1 \mathrm{~mm}$ as shown in Table 1. Furthermore, transparent, white, black, and colored (e.g., red, blue, green, and gray) microplastics were detected in the freshwater of China. In general, white and transparent account for the majority. In addition, the main types of polymers detected in surface water of China are PP, PE, PS, and PET. In parallel to this, the PP and PE microplastics account for the most proportion as described Table 1. 
Table 2. The abundance and characteristics of microplastics in sediments

\begin{tabular}{|c|c|c|c|c|c|c|c|c|c|}
\hline Sediment & Location & Abundance & Size & Sampling & Shape & Color & Polymer types & Identification & Ref. \\
\hline & Dafeng River & $\begin{array}{l}\text { 9.4-50.3 items } / \mathrm{kg} \text { (dry } \\
\text { weight) } 0.0-21.3 \text { items } / \mathrm{kg}\end{array}$ & $\begin{array}{l}<1 \mathrm{~mm} \\
\text { (dominant) }\end{array}$ & Van Veen grab & Fiber (dominant) & - & PET (dominant) & Microscope; FTIR & {$[8]$} \\
\hline & $\begin{array}{l}\text { West River } \\
\text { (lower) }\end{array}$ & $2560-10,240$ items $/ \mathrm{kg}$ & $\begin{array}{l}<0.5 \mathrm{~mm} \\
\text { (dominant) }\end{array}$ & Grab bucket & $\begin{array}{l}\text { Fiber (dominant), pellet, } \\
\text { fragment, and film }\end{array}$ & - & $\begin{array}{l}\text { PP (38\%), PE (27\%), PS } \\
(16 \%), \text { PET }(4 \%), \text { PVC } \\
(6 \%)\end{array}$ & Microscope; FTIR & [19] \\
\hline & $\begin{array}{l}\text { Minjiang River } \\
\text { (Chengdu) }\end{array}$ & $573.84-2878.97$ items $/ \mathrm{kg}$ & $<5 \mathrm{~mm}$ & $\begin{array}{l}\mathrm{CN}-200 \text { piston } \\
\text { column mud }\end{array}$ & $\begin{array}{l}\text { Particle (5.1\%), fragment } \\
(65.7 \%) \text { and fiber (29.3\%) }\end{array}$ & - & $\begin{array}{l}\text { PP (26\%), PE (21\%), RA } \\
(16 \%)\end{array}$ & Microscope; FTIR & [23] \\
\hline & Taihu Lake & $460-1380$ items/kg & $\begin{array}{l}<100 \mu \mathrm{m} \\
(70 \%)\end{array}$ & Peterson grab & - & - & $\begin{array}{l}\text { PVC and PE (dominant), } \\
\text { PS, PP }\end{array}$ & $\begin{array}{l}\text { Microscope; FTIR; } \\
\text { SEM }\end{array}$ & {$[24]$} \\
\hline & Poyang Lake & $\begin{array}{l}(821 \pm 100-1936 \pm 121 \\
\text { items } / \mathrm{kg})\end{array}$ & $<5 \mathrm{~mm}$ & $\begin{array}{l}\text { Stainless-steel } \\
\text { shovel }\end{array}$ & $\begin{array}{l}\text { Fragment (dominant), fiber, } \\
\text { film, foam }\end{array}$ & - & $P P, P V C, P E, P S$, and PVA & $\begin{array}{l}\text { Microscope; FTIR; } \\
\text { SEM }\end{array}$ & [31] \\
\hline & Qinghai Lake & $50-1292$ items $/ \mathrm{m}^{2}$ & $<5 \mathrm{~mm}$ & $\begin{array}{l}\text { Stainless-steel } \\
\text { shovel }\end{array}$ & Fiber, sheet & - & $\begin{array}{l}\text { PP, PE (dominant), EVA, } \\
\text { PVC, PC }\end{array}$ & $\begin{array}{l}\text { Microscope; } \\
\text { Raman }\end{array}$ & [32] \\
\hline & $\begin{array}{l}\text { Danjiangkou } \\
\text { Reservoir }\end{array}$ & $708-3237$ items/kg & $\begin{array}{l}<200 \mu \mathrm{m} \\
(21.7 \%) \\
200-500 \mu \mathrm{m} \\
(35.2 \%) \\
500-1000 \mu \mathrm{m} \\
(23.4 \%) \\
>1000 \mu \mathrm{m} \\
(19.6 \%)\end{array}$ & Van Veen grab & $\begin{array}{l}\text { Fiber }(52.8 \%) \text {, fragment } \\
(42.3 \%) \text {, film (3.87\%), pellet } \\
(1.2 \%) \text {, }\end{array}$ & $\begin{array}{l}\text { Transparent (51.4\%) and brown } \\
(33.0 \%)\end{array}$ & - & $\begin{array}{l}\text { Microscope; } \\
\text { Raman }\end{array}$ & {$[36]$} \\
\hline & $\begin{array}{l}\text { Three Gorges } \\
\text { Reservoir }\end{array}$ & $25-300$ items $/ \mathrm{kg}$ & $0.5-5 \mathrm{~mm}$ & Van Veen grab & $\begin{array}{l}\text { Fiber (dominant), fragment, } \\
\text { pellet, film and foam }\end{array}$ & Transparent (dominant) & - & $\begin{array}{l}\text { Microscope; } \\
\text { Raman; SEM }\end{array}$ & [37] \\
\hline & Pearl River & $80-9597$ items $/ \mathrm{kg}$ & $\begin{array}{l}0.02-1 \mathrm{~mm} \\
(65.3 \%) \\
1-2 \mathrm{~mm} \\
(29.5 \%) \\
2-3 \mathrm{~mm}(7.6 \%) \\
3-4 \mathrm{~mm}(3.3 \%) \\
4-5 \mathrm{~mm}(1.6 \%)\end{array}$ & Van Veen grab & $\begin{array}{l}\text { Fiber }(54.7 \%) \text {, fragment } \\
(43.3 \%)\end{array}$ & $\begin{array}{l}\text { White }(65.5 \%) \text {, red, black, blue, } \\
\text { yellow, green, and transparent }\end{array}$ & $\begin{array}{l}\mathrm{PE}(47.6 \%) \text { and PP } \\
(26.2 \%)\end{array}$ & Microscope; FTIR & {$[42]$} \\
\hline & Yongfeng River & $\begin{array}{l}5-72 \text { items } / \mathrm{kg},(26 \pm 23 \\
\text { items } / \mathrm{kg})\end{array}$ & $\begin{array}{l}<1 \mathrm{~mm} \\
\text { (dominant) }\end{array}$ & $\begin{array}{l}\text { Peterson gravity } \\
\text { sampler }\end{array}$ & Film (64.4\%), fiber (33.9\%) & $\begin{array}{l}\text { Transparent and green } \\
\text { (dominant) }\end{array}$ & $\begin{array}{l}\text { PP (24\%), PE (61\%), PET } \\
(8 \%)\end{array}$ & FTIR; SEM & {$[56]$} \\
\hline & Qin River & $0-97$ items $/ \mathrm{kg}$ & $1-5 \mathrm{~mm}(76 \%)$ & Grab dredge & $\begin{array}{l}\text { Fiber }(30.9 \%) \text {, sheets } \\
(62.8 \%), \text { fragment }(6.3 \%)\end{array}$ & $\begin{array}{l}\text { White }(30 \%) \text {, blue }(27.6 \%) \text {, } \\
\text { green }(18.3 \%) \text {, red }(18.5 \%) \\
\text { black }(1.5 \%) \text {, }\end{array}$ & $\begin{array}{l}\text { PP (55.3\%), PET (21.3\%), } \\
\text { and PE (17.0\%) }\end{array}$ & Microscope; FTIR & [79] \\
\hline & Wei River & 360-1320 items $/ \mathrm{kg}$ & $\begin{array}{l}<0.5 \mathrm{~mm} \\
\text { (dominant) }\end{array}$ & Garb & Fiber and film (dominant) & - & - & Microscope; SEM & [81] \\
\hline & Fuhe River & $\begin{array}{l}212 \pm 14-1049 \pm 212 \\
\text { items } / \mathrm{kg}\end{array}$ & $\begin{array}{l}\text { 0.1-1 mm } \\
\text { (dominant) }\end{array}$ & $\begin{array}{l}\text { Columnar } \\
\text { sampler }\end{array}$ & $\begin{array}{l}\text { Fragment and fiber } \\
\text { (dominant), film,pellet }\end{array}$ & Transparent (dominant) & $P E T, P P, P E, P A$ & Microscope; FTIR & {$[83]$} \\
\hline
\end{tabular}


In this review, we counted the microplastic pollution in 13 rivers including the Yangtze River, the Yellow River, the Pearl River, and the Qiantang River. In the river of China, the main shapes of microplastics are fibers and fragments, and the size of most microplastics is less than $1 \mathrm{~mm}$. The main polymer types of microplastics are found to be PP and PE. This could be the case because of the excellent yield and wide utilization of PP and PE in our daily lives, such as plastic bottles, bags, films, lids, and containers ${ }^{[2]}$. Though transparent and white colors are the main colors of the detected microplastics in Chinese rivers. As shown in Table 1, the abundance of microplastics in the Yellow River, Yangtze River, and Pearl River Delta, which are the three main rivers in China, is significantly higher than the abundance of the Qiantang River, Minjiang River, and other rivers ${ }^{[5,23,25-27]}$. The surrounding population of these three rivers is dense, and the degree of urbanization and economic development is higher than other regions of China, indicating the microplastic pollution could be closely related to the society and economy of the freshwater neighborhood. Similarly, Eo et al. ${ }^{[28]}$ (2019) and Alam et al. ${ }^{[29]}$ (2019) found that microplastic pollution in densely populated areas is equally serious. Besides this, microplastics were also found in the surface waters of the Chinese remote Qinghai-Tibet Plateau, such as the Yarlung Zangbo River, Tongtian River, and Nu River. This indicates that the microplastics have become the ubiquitous pollutant ${ }^{[30]}$. Similarly, microplastics were detected in the freshwater of the Antarctic Special Reserve ${ }^{[6]}$. These findings disclose that microplastic pollution has spread all over the world, and in the absence of monitoring, microplastics may transfer and spread under the impact of monsoons, runoffs, and other factors.

To study lakes, we selected the four largest lakes in China (e.g., Poyang Lake, Taihu Lake, Dongting Lake, and Qinghai Lake) and Honghu Lake ${ }^{[24,31-33]}$. In conclusion, the particle size of microplastics in Chinese lakes is mainly less than $2 \mathrm{~mm}$ as demonstrated in Table 1. Similar to rivers, fibers and fragments are found to be the main shapes of microplastics in lakes. At the same time, PP and PE are the main polymer types as shown in Table 1. The reason behind this phenomenon could be linked to the transportation of microplastics to lakes along with rivers ${ }^{[24]}$. The examination of the lake flowing through the river found that the abundance of microplastics in the inflow river is, generally, lower compared to the one found in the outflow river ${ }^{[24]}$. Among all lakes, Honghu Lake $\left(2282.5 \mathrm{items} / \mathrm{m}^{3}\right.$ ) has the highest abundance of microplastics, followed by Dongting Lake $\left(1191.7 \mathrm{items} / \mathrm{m}^{3}\right)$, and Poyang Lake $\left(289 \pm 40-1064 \pm 90 \mathrm{items} / \mathrm{m}^{3}\right)^{[31,33]}$. There is also a high abundance of microplastics in Qinghai Lake $\left(0.05 \times 10^{5}-7.58 \times 10^{5}\right.$ items $\left./ \mathrm{km}^{2}\right)$ and Taihu Lake $(5.67 \pm 1.92 \text { items } / \mathrm{L})^{[24,32]}$. Hong Lake is adjacent to Dongting Lake. However, compared with Dongting Lake, Hong Lake is more closed and has a smaller water surface area. Consequently, these could be the reasons for its high abundance ${ }^{[33]}$. On the other hand, Qinghai Lake is different from other lakes, there is no industry in the Qinghai Lake basin, and the population is also low. However, it has a plenty of tourism resources, which are the primary cause of the observed high abundance of microplastics ${ }^{[32]}$. At the same time, large amounts of microplastics have been found in lakes in other countries, such as Red Hills Lake in India $\left(5900 \mathrm{items} / \mathrm{m}^{3}\right)$ and three subalpine lakes in Italy $\left(43,000 \mathrm{items} / \mathrm{km}^{2}\right)^{[34,35]}$.

In China, microplastics are not just detected in rivers and lakes but also in reservoirs. The Three Gorges Reservoir and Danjiangkou Reservoir are the main reservoirs in China. The characteristics of the microplastics in these two reservoirs are like other freshwater environments, mainly transparent fibers and fragments. The particle size of most microplastics is less than $1 \mathrm{~mm}$ as shown in Table 1. Considering the function of the reservoir, the reservoir may be a potential area for the accumulation of microplastics. The abundance of microplastics in the Three Gorges Reservoir $\left(4703 \pm 2816 \mathrm{items} / \mathrm{m}^{3}\right)$ and Danjiangkou Reservoir $\left(7205 \mathrm{items} / \mathrm{m}^{3}\right)$ is much higher than Poyang Lake $\left(289 \pm 40-1064 \pm 90\right.$ items $\left./ \mathrm{m}^{3}\right)$, Hong Lake $\left(2282.5 \mathrm{items} / \mathrm{m}^{3}\right)$, and Dongting Lake $\left(1191.7 \mathrm{items} / \mathrm{m}^{3}\right)^{[31,33,36,37]}$. Meanwhile, the amount of microplastics in the Three Gorges Reservoir is one hundred thousand times that in the Feilaixia Reservoir $\left(0.56 \pm 0.45\right.$ items $\left./ \mathrm{m}^{3}\right)$. It might be because the larger the total intake capacity of the reservoir, the higher the 
Table 3. The abundance and characteristics of microplastics in biota

\begin{tabular}{|c|c|c|c|c|c|c|}
\hline Biota & Location & Identification & Average abundance (range) & Size & Shape & Ref. \\
\hline $\begin{array}{l}\text { Wild Freshwater } \\
\text { fish }\end{array}$ & Beijiang River & Microscope & $\begin{array}{l}\text { 1.0-15.0 items/individual } \\
\text { (average 5.6) }\end{array}$ & $\begin{array}{l}<0.5 \mathrm{~mm} \\
(>50 \%)\end{array}$ & $\begin{array}{l}\text { Fragment and fiber } \\
(>90 \%)\end{array}$ & {$[5]$} \\
\hline $\begin{array}{l}\text { Wild Freshwater } \\
\text { fish }\end{array}$ & Pearl River Delta & Microscope & $\begin{array}{l}\text { 1.0-14.0 items/individual } \\
\text { (average } 4.8 \text { ) }\end{array}$ & $\begin{array}{l}<0.5 \mathrm{~mm} \\
(>50 \%)\end{array}$ & $\begin{array}{l}\text { Fragment and fiber } \\
(>90 \%)\end{array}$ & \\
\hline Wild fishes & Dafeng river & $\begin{array}{l}\text { Microscope } \\
\text { FTIR }\end{array}$ & $\begin{array}{l}8 \times 10^{3}-5.7 \times 10^{4} \text { items } / \mathrm{kg}(0.3- \\
6.7 \text { items/individual digestive } \\
\text { tract) } \\
2 \times 10^{3}-1.7 \times 10^{4} \text { items } / \mathrm{kg} \\
(0.1-3.0 \text { items/individual gill) }\end{array}$ & $\begin{array}{l}0.5-5 \mathrm{~mm} \\
\text { (dominant) }\end{array}$ & Fiber (dominant) & {$[8]$} \\
\hline $\begin{array}{l}\text { Gymnocypris } \\
\text { przewalskii }\end{array}$ & Qinghai Lake & Raman & 2-15 items/individual & - & Fiber, sheet & {$[32]$} \\
\hline $\begin{array}{l}\text { Asian clam } \\
\text { (Corbicula } \\
\text { fluminea) }\end{array}$ & $\begin{array}{l}\text { Middle-Lower } \\
\text { Yangtze River }\end{array}$ & FTIR & $\begin{array}{l}\text { 0.4-5.0 items/individual } \\
\text { (0.3-4.9 items/g) }\end{array}$ & $\begin{array}{l}0.021-4.83 \\
\mathrm{~mm} \\
0.25-1 \mathrm{~mm} \\
\text { (dominant) }\end{array}$ & Fiber (60\%-100\%) & [43] \\
\hline $\begin{array}{l}\text { Wild crucians } \\
\text { (Carassius auratus) }\end{array}$ & Poyang Lake & $\begin{array}{l}\text { Microscope; } \\
\text { Raman }\end{array}$ & 0-18 items/individual & $\begin{array}{l}>0.5 \mathrm{~mm} \\
(82.1 \%)\end{array}$ & Fiber (dominant) & {$[46]$} \\
\hline $\begin{array}{l}\text { Wild fishes ( } 4 \\
\text { species) }\end{array}$ & Lijiang River & FTIR & $0.6 \pm 0.6$ items/individual & $\begin{array}{l}>1 \mathrm{~mm}(60 \%- \\
100 \%)\end{array}$ & Fiber (dominant) & {$[80]$} \\
\hline Wild organisms & Liaohe Estuary & $\begin{array}{l}\text { Stereomicroscope } \\
\text { FTIR }\end{array}$ & $\begin{array}{l}0.83 \pm 0.99-3.87 \pm 2.18 \\
\text { items/individual }\end{array}$ & $\begin{array}{l}<1 \mathrm{~mm} \\
\text { (dominant) }\end{array}$ & $\begin{array}{l}\text { Fiber (dominant), } \\
\text { fragment, pellet }\end{array}$ & [82] \\
\hline Reed & Dongting Lake & $\begin{array}{l}\text { Microscope } \\
\text { FTIR }\end{array}$ & 0-14 items/individual & $\begin{array}{l}<0.5 \mathrm{~mm} \\
(56 \%-68 \%) \\
0.5-1 \mathrm{~mm} \\
(24 \%) \\
1-3 \mathrm{~mm}(10 \%) \\
3-5 \mathrm{~mm}(3 \%)\end{array}$ & $\begin{array}{l}\text { Fiber (59\%-100\%) } \\
\text { (average value of } \\
89 \%)\end{array}$ & [84] \\
\hline Tilapia & $\begin{array}{l}\text { North and west rivers } \\
\text { of Guangdong } \\
\text { province }\end{array}$ & Microscope & $\begin{array}{l}\text { 0-18.0 items/individual } \\
(0-0.116 \text { items } / g)\end{array}$ & $\begin{array}{l}<1 \mathrm{~mm} \\
(>72.5 \%)\end{array}$ & $\begin{array}{l}\text { Fragment and fiber } \\
\text { (dominant) }\end{array}$ & [85] \\
\hline Mud carp & $\begin{array}{l}\text { North and west rivers } \\
\text { of Guangdong } \\
\text { province }\end{array}$ & Microscope & $\begin{array}{l}\text { 0-14.0 items/individual } \\
(0-0.385 \text { items } / g)\end{array}$ & $\begin{array}{l}<1 \mathrm{~mm} \\
(>72.5 \%)\end{array}$ & $\begin{array}{l}\text { Fragment and fiber } \\
\text { (dominant) }\end{array}$ & \\
\hline
\end{tabular}

opportunities to collect microplastics ${ }^{[38]}$.

The freshwater resources of rivers, reservoirs, and lakes are generally used to regulate water supply, agricultural irrigation, and aquaculture ${ }^{[5]}$. Water with a high abundance of microplastics, used for agricultural irrigation, might aggravate the microplastics pollution in soil and cause potential harm to crops $^{[39]}$. In parallel to that, aquaculture in waters, containing a high abundance of microplastics, does not only affect the growth and development of aquatic organisms extremely, but also allows the microplastics to reach the human body, through the food chain, causing various health issues ${ }^{[40]}$.

\section{Sediments}

Sediment is an important accumulation pool of microplastics in rivers, lakes, and reservoirs ${ }^{[41]}$. According to the findings of many previous studies, a lot of microplastics were accumulated in the sediment of rivers, lakes, and reservoirs. Basically, sediment sampling is generally carried out with grab buckets, stainless steel shovels, and cylindrical samplers to take the upper layer (usually o to $20 \mathrm{~cm}$ ) sediment as demonstrated in Table 2. The average abundance of microplastics in the sediment of freshwater were ranging between 460 and 10240 items/kg or 0 to 1292 items $/ \mathrm{m}^{2}$ as can be seen from Table 2. More severe microplastics pollution levels were found in the sediments of West River, Pearl River, Danjiangkou Reservoir, and Minjiang (Chengdu) $)^{[19,23,36,42]}$. Similar to water, the main shapes of microplastics in sediments are fragments and fibers as shown in Table 2. On the other hand, the main shape of microplastics in the sediment of Qin River is 


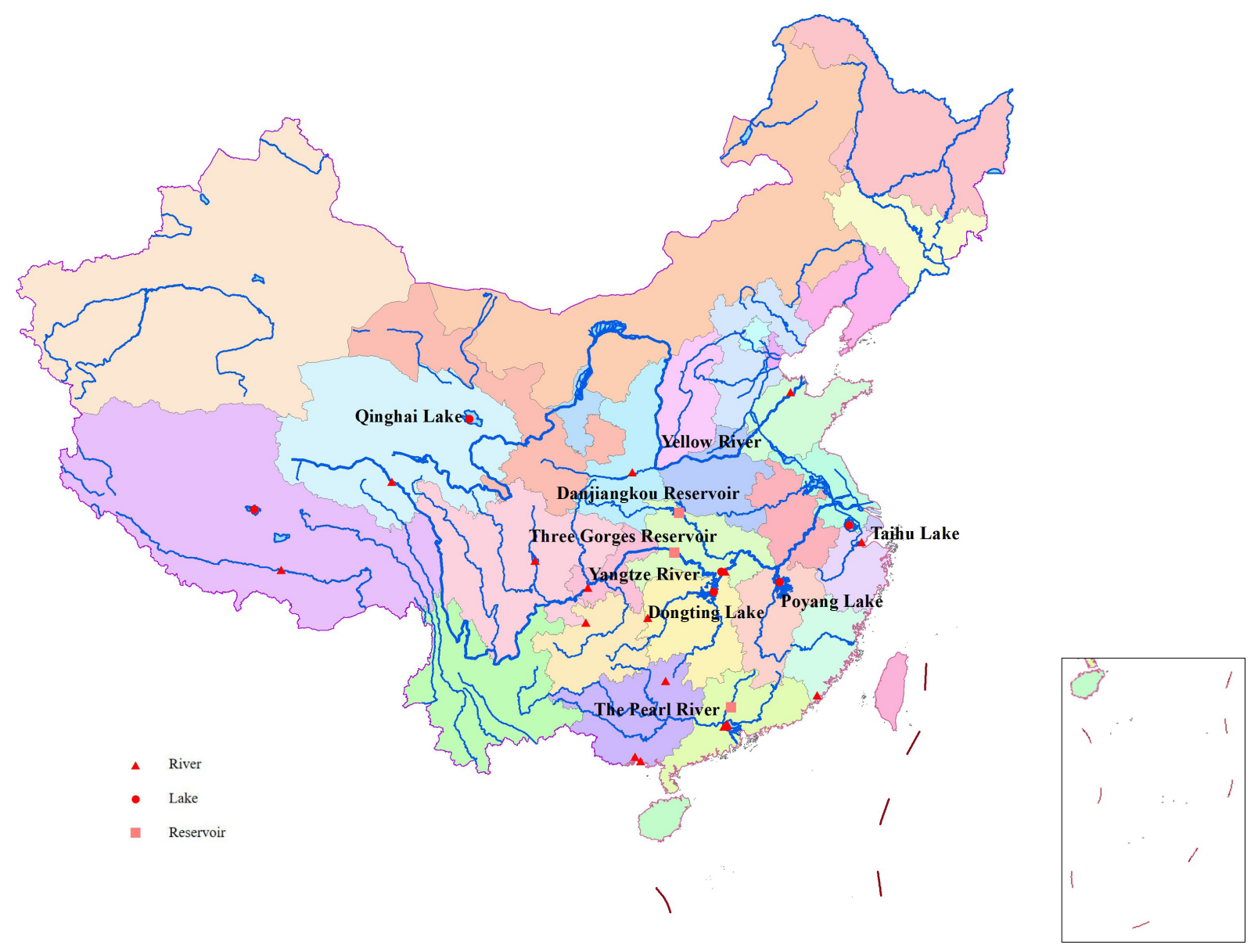

Figure 1. Distribution map of study locations.

sheet. Additionally, the main types of microplastics in sediments of the freshwater environment in China are PP and PE. Among all sediments of freshwater in China, the pollution of microplastics in the sediments of the Pearl River system is the most critical one as depicted in Table 2. The abundance of microplastics in the downstream sediments in the West River, which is the longest river in the Pearl River Basin, is much higher compared to other water bodies. The high abundance of microplastics observed in West River, was likely due to two reasons, the first downstream industries being well developed and the other sampling areas including commercial and industrial areas, which are significantly affected by humans ${ }^{[19]}$. Meanwhile, the abundance of microplastics in the sediments of Danjiangkou Reservoir is higher compared to other water bodies (except the Pearl River Basin). This might be due to the low flow velocity of Danjiangkou Reservoir which reduces the loss of microplastics ${ }^{[36]}$. Generally, the microplastics in the sediments can be ingested by benthic organisms and affect their physiological activity and metabolism ${ }^{[43]}$. Furthermore, it can be transported to high-trophic organisms along the food chain. The status of microplastics in the sediments of the freshwater environment in China is similar to other countries. For example, Mani et al. ${ }^{[44]}$ (2019) found that the range of microplastics in the sediments of the Rhine River in Germany was $260 \pm 10$ to 11,070 \pm 600 items $/ \mathrm{kg}$. On contrary, the range of microplastics in Ciwalengke River sediments in Indonesia is only $30.3 \pm 15.9$ items $/ \mathrm{kg}^{[29]}$. 


\section{Biota}

Microplastics in water bodies and sediments can easily reach aquatic organisms. Therefore, aquatic organisms can be used as an indicator to the level of microplastic pollution in the region ${ }^{[45]}$. Previous biological studies were mostly concentrating on the tropical and subtropical regions of southern China. At the same time, all biota samples were directly from sampling or purchasing. Studies reported that some aquatic plants, bivalves (e.g., Asian clams) and fish (e.g., Oreochromis niloticus, Cirrhinus molitorella, and Carassius auratus) all contained microplastics. The abundance range of microplastics in aquatic organisms was 0 to 18 items/individual, with the highest concentrations in Poyang Lake and north and west rivers of Guangdong province. Among them all, the abundance of microplastics in wild fish, in the Lijiang River, was significantly lower than others. It is an indication that the Lijiang River was less polluted by microplastics. Basically, the characteristics of microplastics in aquatic organisms are like the ones in water and sediments. The shape of the microplastics in the aquatic organisms is mainly fiber, and the particle size of most microplastics is less than $1 \mathrm{~mm}$ as shown in Table 3. This might be so because fish ingesting microplastic fibers as plant fibers. The researchers found that the type of fish, feeding pattern, and habitat all can affect the level of microplastic enrichment. For example, fish may accumulate microplastics in the different tissues through diverse feeding methods such as swallowing, sucking, and filter feeding ${ }^{[46,47]}$. In Beijiang and Pearl River Deltas of China, the microplastic abundances of carnivorous fish were 3.5 and 3 items/individual, respectively. Similarly, the microplastic abundances of omnivorous fish were 6.8 and 6.2 items/individual, respectively ${ }^{[5]}$. The result revealed that omnivorous fish are more likely to accumulate microplastics than carnivorous fish. In parallel to this, Zheng et al. ${ }^{[48]}$ (2019) found that benthic fish, generally, accumulate more microplastics than other fishes in the water. The contamination status of microplastics in freshwater organisms, in China, is consistent with those of other countries. In Bangladesh, the abundance range of microplastics for fish is 2 to 6 items/individual ${ }^{[49]}$. At the same time, the abundance range of microplastics in freshwater fishes, in southwestern Germany, is 1 to 4 items/individual ${ }^{[50]}$. Although, the abundance and type of microplastics in biota of freshwater environments, in China, have been investigated in recent years, more studies should be carried to comprehensively evaluate the MP pollution in freshwater ecosystem of China.

\section{MICROPLASTICS SOURCE IN THE FRESHWATER ENVIRONMENT}

Microplastic pollution of the freshwater environment is associated with geographical location, human activities, and other factors ${ }^{[5]}$. Exploring the source of microplastics can help us reduce the pollution of microplastics in the freshwater environment. Essentially, the distribution of microplastics is closely related to population, industry, and the degree of urbanization. For example, in the densely populated and economically developed Pearl River Delta, the middle, and lower reaches of the Yangtze River, microplastics pollution is more severe compared to other regions ${ }^{[5,25]}$.

Chinese freshwater environment is mainly polluted by microplastics through the following channels: domestic wastewater, surface runoff, atmospheric transportation, and aquaculture ${ }^{[51]}$. Domestic wastewater is the main source of microplastics in the water body, near the urban regions. In the city, sewage treatment plants are concentrated areas for the collection and treatment of domestic sewage. Although the sewage treatment plant can process up to $99 \%$ of microplastics, a considerable amount of microplastics passes through this system and is discharged into the water body along with the sewage ${ }^{[52-54]}$. Although the four sewage treatment plants in Guilin, Guangxi have high removal efficiency, each sewage treatment plant discharges 2 to 78 million items of microplastics into the receiving water body every day ${ }^{[52]}$. In the underdeveloped countryside of China, sanitary sewage is discharged directly into the water environment with simple or no treatment causing serious microplastics pollution. Likewise, landfills transport microplastics to the environment through the leaching of landfill leachat ${ }^{[54]}$. Meanwhile, rainwater runoff (especially during periods of heavy rainfall) is also an essential way for the terrestrial ecosystem to transport microplastics to the aquatic ecosystem. On the banks of the river, lake, and reservoir, there are plastic 
containers (e.g., plastic bags), fishing nets, and lines that are randomly discarded which increase the risk of microplastic pollution when these plastics are weathered ${ }^{[51]}$. Furthermore, Li et al. ${ }^{[55]}$ (2020) indicated that inappropriate management of these waste plastics is the principal reason behind the microplastic pollution in the water of the Yangtze River Estuary. At the same time, some agricultural activities produce microplastics in the soil then transfer them to the water environment by means of surface runoff ${ }^{[56]}$. Additionally, rainfall and atmospheric deposition are one of the primary sources of microplastics in some remote $\operatorname{areas}^{[57]}$. Either, in cities or rural areas, aquaculture is one of the core sources of microplastics for lakes ${ }^{[58,59]}$. Moreover, tourism is also a fundamental source of microplastics in some areas, such as Qinghai and the Qinghai-Tibet Plateau ${ }^{[32,60]}$.

\section{IMPACTS OF MICROPLASTICS ON THE FRESHWATER ENVIRONMENT}

The impact of microplastics on the freshwater ecosystem can be divided into physical and chemical impacts, with the chemical one being the dominant. Basically, the physical impact, of microplastics on the environment, primarily depends on particle characteristics. There are two main reasons for the chemical pollution of microplastics to the freshwater environment. First, the additives released from microplastics that aggravate the pollution of the water environment and second the toxic pollutants adsorbed in microplastics that increase its harm to organisms. Plastics usually contain various additives, such as plasticizers, heat stabilizers, colorants, foaming agents, and heavy metals ${ }^{[6]}$. It is considered to be carcinogenic and can damage the endocrine system. Once these additives leached from microplastics do not only pollute the water environment but cause potential harm to aquatic organisms ${ }^{[62]}$. For example, lead $\mathrm{Pb})$ released from PVC affects the gene expression in zebrafish ${ }^{[63]}$. Moreover, microplastics would adsorb persistent organic pollutants (e.g., PCBs, PAHs, DDTs, and PBDEs) and heavy metals (e.g., $\mathrm{Cr}, \mathrm{Cu}, \mathrm{Ni}, \mathrm{Pb}$, $\mathrm{Cd}$, and $\mathrm{Zn}$ ) due to their larger specific surface area and hydrophobicity ${ }^{[64-67]}$ thus increasing the toxicity of microplastics. At the same time, persistent organic pollutants and heavy metals can cause secretion disorders, mutations, and cancer in organisms. Later, these pollutants can reach high-nutrient organisms through the food chain ${ }^{[68]}$.

In addition to indirectly affecting aquatic organisms by affecting the water environment, microplastics can directly cause physical and chemical damage to organisms through ingestion ${ }^{[60]}$. The ingestion of microplastics, by fish and benthic organisms, may cause abrasions, ulcers, and blockages of the digestive tract. This, in turn, affects the growth and metabolism of these organisms ${ }^{[10,70]}$. Fish ingesting microplastics might cause liver poisoning and inflammation ${ }^{[71]}$. Furthermore, Jin et al. ${ }^{[72]}$ (2018) and Park et al. ${ }^{[73]}(2022)$ indicated that the PE microplastics could cause inflammation of zebrafish, damage to the liver, and microbiota to crucian carp. Microplastics do not only affect the development of fish embryos but also influence their gene expression ${ }^{[7]}$. For example, Umamaheswari et al. ${ }^{[75]}$ (2020) found that PE microplastics affect genes (e.g., cat, sod1, gpx1a, gstp1, hsp70l, ptgs2a, and ache) expression in zebrafish. Moreover, microplastics could change the natural habitat, disturb the bacterial community, disrupt the development of species, and adversely affect the ecological functions of the aquatic ecosystem ${ }^{[76]}$. For example, the existence of microplastics reduced the chlorophyll content of algae, thereby decreasing the efficiency of photosynthesis and inhibiting the growth of algae ${ }^{[77]}$. Inhibition of algae growth represents a decrease in primary consumers in the environment, which may have an impact on the nutrient cycle in the aquatic ecosystem $^{[78]}$.

\section{PROSPECTIVE AND SUGGESTIONS}

Microplastic pollution, in the freshwater environment of China, is associated with both natural and human factors. Different regions have different distribution characteristics of microplastics and even the same freshwater area showed different results, of the microplastics abundance, due to different sampling methods, 
extraction methods, identification methods and units expression. These factors are not conducive to the follow-up evaluation and treatment of microplastics pollution. Therefore, in the future, a unified standard unit representation, sampling, and detecting methods are suggested to better measure and evaluate the status of microplastics.

Furthermore, the sources of microplastics in water are extremely wide, and the control methods are also diverse. Domestic wastewater is one of the principal sources of microplastics in freshwater, thus improving the treatment efficiency of microplastics in wastewater treatment plants can help to effectively control the input of microplastics. Meanwhile, increasing the recovery of the discarded plastics, effectively disposing them in agricultural activity, raising the public awareness of microplastics, and reducing the random discard of plastic products are all of a great significance. In addition to that, tourism is considered the main source of microplastics in remote regions such as Qinghai and Qinghai-Tibet Plateau. Consequently, strengthening supervision and management in this area are one of the key methods to reduce microplastic pollution.

Although some experiments have been done to explore the harm of different microplastics and particle size to organisms of freshwater environment, the comprehensive impact of microplastics on organisms, in the ecosystem, is still unknown. Therefore, exploring microplastics fate in the freshwater environment and evaluating the impact of microplastics on the biota, especially their potential harm to human health, should be brought to the forefront.

\section{CONCLUSION}

Microplastic pollution in the freshwater environment of China has become widespread. The abundance of microplastics in areas with intensive human activity (e.g., Pearl River Region) is much higher compared to remote areas (e.g., the Qinghai-Tibet Plateau). The shape of microplastics in the freshwater environment is mainly fragments and fibers, and the types are essentially PP and PE. At the same time, the key sources of microplastics are sewage discharge, surface runoff, and aquaculture. The aquatic organisms, in the freshwater of China, are also polluted by microplastics, especially the bivalves and fishes, which aggravate the accumulation of microplastics in the human body. Although microplastics have been attracting more attention and turned into a trending topic in the last few years, there is still a lack of in-depth research on the sources of microplastics and the harm to the human body. To prevent microplastic pollution, governments, of all countries, should issue relevant policies and regulations, as soon as possible, to reduce their pollution.

\section{DECLARATIONS}

\section{Acknowledgments}

This work was supported by the National Natural Science Foundation of China (Grant No. 42007349), Young Talent fund of University Association for Science and Technology in Shaanxi, China (20200202) and Key Research and Development Project of Shaanxi Province (No. 2020SF-366).

\section{Authors' contributions}

Made substantial contributions to conception and design of the study and performed data analysis and interpretation: Zhao H, Zhou Y, Han Y

Performed data acquisition, as well as provided administrative and technical support: Sun Y, Ren X, Zhang $\mathrm{Z}$

Supervision, project administration and writing-review \& editing: Wang Q 


\section{Availability of data and materials}

Not applicable.

\section{Financial support and sponsorship}

This work was supported by the National Natural Science Foundation of China (Grant No. 42007349) and Young Talent fund of University Association for Science and Technology in Shaanxi, China (20200202).

\section{Conflicts of interest}

All authors declared that there are no conflicts of interest.

\section{Ethical approval and consent to participate}

Not applicable.

\section{Consent for publication}

Not applicable.

\section{Copyright}

(C) The Author(s) 2022

\section{REFERENCES}

1. Cózar A, Echevarría F, González-Gordillo JI, et al. Plastic debris in the open ocean. Proc Natl Acad Sci U S A 2014;111:10239-44. DOI PubMed PMC

2. Plastics - the Facts 2020 an Analysis of European Plastics Production, Demand and Waste Data, Plastics Europe. Association of Plastics Manufacturers, Brussels, Belgium (2020). Available from: https://plasticseurope.org/knowledge-hub/plastics-the-facts-2020/ [Last accessed on 1 Mar 2022].

3. Liu S, Huang J, Zhang W, et al. Microplastics as a vehicle of heavy metals in aquatic environments: a review of adsorption factors, mechanisms, and biological effects. J Environ Manage 2021;302:113995. DOI PubMed

4. Yang S, Zhou M, Chen X, et al. A comparative review of microplastics in lake systems from different countries and regions. Chemosphere 2022;286:131806. DOI PubMed

5. Wang S, Zhang C, Pan Z, et al. Microplastics in wild freshwater fish of different feeding habits from Beijiang and Pearl River Delta regions, south China. Chemosphere 2020;258:127345. DOI PubMed

6. González-Pleiter M, Edo C, Velázquez D, et al. First detection of microplastics in the freshwater of an Antarctic Specially Protected Area. Mar Pollut Bull 2020;161:111811. DOI PubMed

7. Morgana S, Ghigliotti L, Estévez-Calvar N, et al. Microplastics in the Arctic: a case study with sub-surface water and fish samples off Northeast Greenland. Environ Pollut 2018;242:1078-86. DOI PubMed

8. Liu S, Chen H, Wang J, et al. The distribution of microplastics in water, sediment, and fish of the Dafeng River, a remote river in China. Ecotoxicol Environ Saf 2021;228:113009. DOI PubMed

9. Horton AA, Walton A, Spurgeon DJ, Lahive E, Svendsen C. Microplastics in freshwater and terrestrial environments: evaluating the current understanding to identify the knowledge gaps and future research priorities. Sci Total Environ 2017;586:127-41. DOI PubMed

10. Fu Z, Wang J. Current practices and future perspectives of microplastic pollution in freshwater ecosystems in China. Sci Total Environ 2019;691:697-712. DOI PubMed

11. Setälä O, Fleming-Lehtinen V, Lehtiniemi M. Ingestion and transfer of microplastics in the planktonic food web. Environ Pollut 2014;185:77-83. DOI PubMed

12. Talbot R, Chang H. Microplastics in freshwater: A global review of factors affecting spatial and temporal variations. Environ Pollut 2022;292:118393. DOI PubMed

13. Sulistyowati L, Nurhasanah, Riani E, Cordova MR. The occurrence and abundance of microplastics in surface water of the midstream and downstream of the Cisadane River, Indonesia. Chemosphere 2022;291:133071. DOI PubMed

14. Eriksen M, Mason S, Wilson S, et al. Microplastic pollution in the surface waters of the Laurentian Great Lakes. Mar Pollut Bull 2013;77:177-82. DOI PubMed

15. He B, Goonetilleke A, Ayoko GA, Rintoul L. Abundance, distribution patterns, and identification of microplastics in Brisbane River sediments, Australia. Sci Total Environ 2020;700:134467. DOI PubMed

16. Buwono NR, Risjani Y, Soegianto A. Distribution of microplastic in relation to water quality parameters in the Brantas River, East Java, Indonesia. Environmental Technology \& Innovation 2021;24:101915. DOI

17. Yang L, Zhang Y, Kang S, Wang Z, Wu C. Microplastics in freshwater sediment: a review on methods, occurrence, and sources. Sci Total Environ 2021;754:141948. DOI PubMed

18. Koutnik VS, Leonard J, Alkidim S, et al. Distribution of microplastics in soil and freshwater environments: Global analysis and framework for transport modeling. Environ Pollut 2021;274:116552. DOI PubMed 
19. Huang D, Li X, Ouyang Z, et al. The occurrence and abundance of microplastics in surface water and sediment of the West River downstream, in the south of China. Sci Total Environ 2021;756:143857. DOI PubMed

20. Pan Z, Sun Y, Liu Q, et al. Riverine microplastic pollution matters: a case study in the Zhangjiang River of Southeastern China. Mar Pollut Bull 2020;159:111516. DOI PubMed

21. Li J, Ouyang Z, Liu P, et al. Distribution and characteristics of microplastics in the basin of Chishui River in Renhuai, China. Sci Total Environ 2021;773:145591. DOI PubMed

22. Mao Y, Li H, Gu W, Yang G, Liu Y, He Q. Distribution and characteristics of microplastics in the Yulin River, China: role of environmental and spatial factors. Environ Pollut 2020;265:115033. DOI PubMed

23. Li X, Liang R, Li Y, Zhang Y, Wang Y, Li K. Microplastics in inland freshwater environments with different regional functions: a case study on the Chengdu Plain. Sci Total Environ 2021;789:147938. DOI PubMed

24. Zhang Q, Liu T, Liu L, et al. Distribution and sedimentation of microplastics in Taihu Lake. Sci Total Environ 2021;795:148745. DOI PubMed

25. He D, Chen X, Zhao W, et al. Microplastics contamination in the surface water of the Yangtze River from upstream to estuary based on different sampling methods. Environ Res 2021;196:110908. DOI PubMed

26. Han M, Niu X, Tang M, et al. Distribution of microplastics in surface water of the lower Yellow River near estuary. Sci Total Environ 2020;707:135601. DOI PubMed

27. Zhao W, Huang W, Yin M, et al. Tributary inflows enhance the microplastic load in the estuary: a case from the Qiantang River. Mar Pollut Bull 2020;156:111152. DOI PubMed

28. Eo S, Hong SH, Song YK, Han GM, Shim WJ. Spatiotemporal distribution and annual load of microplastics in the Nakdong River, South Korea. Water Res 2019;160:228-37. DOI PubMed

29. Alam FC, Sembiring E, Muntalif BS, Suendo V. Microplastic distribution in surface water and sediment river around slum and industrial area (case study: Ciwalengke River, Majalaya district, Indonesia). Chemosphere 2019;224:637-45. DOI PubMed

30. Liu RP, Dong Y, Quan GC, et al. Microplastic pollution in surface water and sediments of Qinghai-Tibet Plateau: current status and causes. China Geol 2021;4:178-184. DOI

31. Jian M, Zhang Y, Yang W, Zhou L, Liu S, Xu EG. Occurrence and distribution of microplastics in China's largest freshwater lake system. Chemosphere 2020;261:128186. DOI PubMed

32. Xiong X, Zhang K, Chen X, Shi H, Luo Z, Wu C. Sources and distribution of microplastics in China's largest inland lake - Qinghai Lake. Environ Pollut 2018;235:899-906. DOI PubMed

33. Wang W, Yuan W, Chen Y, Wang J. Microplastics in surface waters of Dongting Lake and Hong Lake, China. Sci Total Environ 2018;633:539-45. DOI PubMed

34. Gopinath K, Seshachalam S, Neelavannan K, et al. Quantification of microplastic in Red Hills Lake of Chennai city, Tamil Nadu, India. Environ Sci Pollut Res Int 2020;27:33297-306. DOI PubMed

35. Sighicelli M, Pietrelli L, Lecce F, et al. Microplastic pollution in the surface waters of Italian Subalpine Lakes. Environ Pollut 2018;236:645-51. DOI PubMed

36. Lin L, Pan X, Zhang S, et al. Distribution and source of microplastics in China's second largest reservoir - Danjiangkou Reservoir. $J$ Environ Sci (China) 2021;102:74-84. DOI PubMed

37. Di M, Wang J. Microplastics in surface waters and sediments of the Three Gorges Reservoir, China. Sci Total Environ 2018;616617:1620-7. DOI PubMed

38. Tan X, Yu X, Cai L, Wang J, Peng J. Microplastics and associated PAHs in surface water from the Feilaixia Reservoir in the Beijiang River, China. Chemosphere 2019;221:834-40. DOI PubMed

39. He D, Luo Y, Lu S, Liu M, Song Y, Lei L. Microplastics in soils: analytical methods, pollution characteristics and ecological risks. TrAC Trends in Analytical Chemistry 2018;109:163-72. DOI

40. Chen G, Li Y, Wang J. Occurrence and ecological impact of microplastics in aquaculture ecosystems. Chemosphere 2021;274:129989. DOI PubMed

41. Simon-Sánchez L, Grelaud M, Garcia-Orellana J, Ziveri P. River Deltas as hotspots of microplastic accumulation: the case study of the Ebro River (NW Mediterranean). Sci Total Environ 2019;687:1186-96. DOI PubMed

42. Lin L, Zuo LZ, Peng JP, et al. Occurrence and distribution of microplastics in an urban river: a case study in the Pearl River along Guangzhou City, China. Sci Total Environ 2018;644:375-81. DOI PubMed

43. Su L, Cai H, Kolandhasamy P, Wu C, Rochman CM, Shi H. Using the Asian clam as an indicator of microplastic pollution in freshwater ecosystems. Environ Pollut 2018;234:347-55. DOI PubMed

44. Mani T, Primpke S, Lorenz C, Gerdts G, Burkhardt-Holm P. Microplastic pollution in benthic midstream sediments of the Rhine River. Environ Sci Technol 2019;53:6053-62. DOI PubMed

45. Pegado TSES, Schmid K, Winemiller KO, et al. First evidence of microplastic ingestion by fishes from the Amazon River estuary. Mar Pollut Bull 2018;133:814-21. DOI PubMed

46. Yuan W, Liu X, Wang W, Di M, Wang J. Microplastic abundance, distribution and composition in water, sediments, and wild fish from Poyang Lake, China. Ecotoxicol Environ Saf 2019;170:180-7. DOI PubMed

47. Li B, Su L, Zhang H, Deng H, Chen Q, Shi H. Microplastics in fishes and their living environments surrounding a plastic production area. Sci Total Environ 2020;727:138662. DOI PubMed

48. Zheng K, Fan Y, Zhu Z, Chen G, Tang C, Peng X. Occurrence and species-specific distribution of plastic debris in wild freshwater fish from the Pearl River Catchment, China. Environ Toxicol Chem 2019;38:1504-13. DOI PubMed

49. Parvin F, Jannat S, Tareq SM. Abundance, characteristics and variation of microplastics in different freshwater fish species from 
Bangladesh. Sci Total Environ 2021;784:147137. DOI PubMed

50. Roch S, Walter T, Ittner LD, Friedrich C, Brinker A. A systematic study of the microplastic burden in freshwater fishes of southwestern Germany - are we searching at the right scale? Sci Total Environ 2019;689:1001-11. DOI PubMed

51. Zhang K, Shi H, Peng J, et al. Microplastic pollution in China's inland water systems: a review of findings, methods, characteristics, effects, and management. Sci Total Environ 2018;630:1641-53. DOI PubMed

52. Zhang L, Liu J, Xie Y, Zhong S, Gao P. Occurrence and removal of microplastics from wastewater treatment plants in a typical tourist city in China. J Clean Prod 2021;291:125968. DOI

53. Murphy F, Ewins C, Carbonnier F, Quinn B. Wastewater Treatment Works (WwTW) as a source of microplastics in the aquatic environment. Environ Sci Technol 2016;50:5800-8. DOI PubMed

54. Hou L, Kumar D, Yoo CG, Gitsov I, Majumder EL. Conversion and removal strategies for microplastics in wastewater treatment plants and landfills. Chem Eng J 2021;406:126715. DOI

55. Li Y, Lu Z, Zheng H, Wang J, Chen C. Microplastics in surface water and sediments of Chongming Island in the Yangtze Estuary, China. Environ Sci Eur 2020:32. DOI

56. Rao Z, Niu S, Zhan N, Wang X, Song X. Microplastics in sediments of River Yongfeng from Maanshan City, Anhui Province, China. Bull Environ Contam Toxicol 2020;104:166-72. DOI PubMed

57. Zhang Y, Kang S, Allen S, Allen D, Gao T, Sillanpää M. Atmospheric microplastics: a review on current status and perspectives. Earth-Science Reviews 2020;203:103118. DOI

58. Ma J, Niu X, Zhang D, et al. High levels of microplastic pollution in aquaculture water of fish ponds in the Pearl River Estuary of Guangzhou, China. Sci Total Environ 2020;744:140679. DOI PubMed

59. Xiong X, Liu Q, Chen X, Wang R, Duan M, Wu C. Occurrence of microplastic in the water of different types of aquaculture ponds in an important lakeside freshwater aquaculture area of China. Chemosphere 2021;282:131126. DOI PubMed

60. Jiang C, Yin L, Li Z, et al. Microplastic pollution in the rivers of the Tibet Plateau. Environ Pollut 2019;249:91-8. DOI PubMed

61. Lithner D, Larsson A, Dave G. Environmental and health hazard ranking and assessment of plastic polymers based on chemical composition. Sci Total Environ 2011;409:3309-24. DOI PubMed

62. Luo H, Xiang Y, He D, et al. Leaching behavior of fluorescent additives from microplastics and the toxicity of leachate to Chlorella vulgaris. Sci Total Environ 2019;678:1-9. DOI PubMed

63. Boyle D, Catarino AI, Clark NJ, Henry TB. Polyvinyl chloride (PVC) plastic fragments release $\mathrm{Pb}$ additives that are bioavailable in zebrafish. Environ Pollut 2020;263:114422. DOI PubMed

64. Jiang X, Tian L, Ma Y, Ji R. Quantifying the bioaccumulation of nanoplastics and PAHs in the clamworm Perinereis aibuhitensis. Sci Total Environ 2019;655:591-7. DOI PubMed

65. Lu K, Qiao R, An H, Zhang Y. Influence of microplastics on the accumulation and chronic toxic effects of cadmium in zebrafish (Danio rerio). Chemosphere 2018;202:514-20. DOI PubMed

66. Kumar R, Sharma P, Manna C, Jain M. Abundance, interaction, ingestion, ecological concerns, and mitigation policies of microplastic pollution in riverine ecosystem: a review. Sci Total Environ 2021;782:146695. DOI

67. Ta AT, Babel S. Microplastic contamination on the lower Chao Phraya: abundance, characteristic and interaction with heavy metals. Chemosphere 2020;257:127234. DOI PubMed

68. Wang W, Gao H, Jin S, Li R, Na G. The ecotoxicological effects of microplastics on aquatic food web, from primary producer to human: a review. Ecotoxicol Environ Saf 2019;173:110-7. DOI PubMed

69. Estahbanati S, Fahrenfeld NL. Influence of wastewater treatment plant discharges on microplastic concentrations in surface water. Chemosphere 2016;162:277-84. DOI PubMed

70. Lei L, Wu S, Lu S, et al. Microplastic particles cause intestinal damage and other adverse effects in zebrafish Danio rerio and nematode Caenorhabditis elegans. Sci Total Environ 2018;619-620:1-8. DOI PubMed

71. Lu Y, Zhang Y, Deng Y, et al. Uptake and accumulation of polystyrene microplastics in zebrafish (Danio rerio) and toxic effects in liver. Environ Sci Technol 2016;50:4054-60. DOI PubMed

72. Jin Y, Xia J, Pan Z, Yang J, Wang W, Fu Z. Polystyrene microplastics induce microbiota dysbiosis and inflammation in the gut of adult zebrafish. Environ Pollut 2018;235:322-9. DOI PubMed

73. Park SH, Kim K. Microplastics induced developmental toxicity with microcirculation dysfunction in zebrafish embryos. Chemosphere 2022;286:131868. DOI PubMed

74. Zhang R, Silic MR, Schaber A, Wasel O, Freeman JL, Sepúlveda MS. Exposure route affects the distribution and toxicity of polystyrene nanoplastics in zebrafish. Sci Total Environ 2020;724:138065. DOI PubMed

75. Umamaheswari S, Priyadarshinee S, Bhattacharjee M, Kadirvelu K, Ramesh M. Exposure to polystyrene microplastics induced gene modulated biological responses in zebrafish (Danio rerio). Chemosphere 2021;281:128592. DOI PubMed

76. Ma H, Pu S, Liu S, Bai Y, Mandal S, Xing B. Microplastics in aquatic environments: toxicity to trigger ecological consequences. Environ Pollut 2020;261:114089. DOI PubMed

77. Xiao Y, Jiang X, Liao Y, Zhao W, Zhao P, Li M. Adverse physiological and molecular level effects of polystyrene microplastics on freshwater microalgae. Chemosphere 2020;255:126914. DOI PubMed

78. Rodrigues MO, Abrantes N, Gonçalves FJM, Nogueira H, Marques JC, Gonçalves AMM. Impacts of plastic products used in daily life on the environment and human health: what is known? Environ Toxicol Pharmacol 2019;72:103239. DOI PubMed

79. Zhang L, Liu J, Xie Y, et al. Distribution of microplastics in surface water and sediments of Qin river in Beibu Gulf, China. Sci Total Environ 2020;708:135176. DOI PubMed

80. Zhang L, Xie Y, Zhong S, Liu J, Qin Y, Gao P. Microplastics in freshwater and wild fishes from Lijiang River in Guangxi, Southwest 
China. Sci Total Environ 2021;755:142428. DOI PubMed

81. Ding L, Mao RF, Guo X, Yang X, Zhang Q, Yang C. Microplastics in surface waters and sediments of the Wei River, in the northwest of China. Sci Total Environ 2019;667:427-34. DOI PubMed

82. Zhou G, Wang Q, Zhang J, et al. Distribution and characteristics of microplastics in urban waters of seven cities in the Tuojiang River basin, China. Environ Res 2020;189:109893. DOI PubMed

83. Zhou Z, Zhang P, Zhang G, Wang S, Cai Y, Wang H. Vertical microplastic distribution in sediments of Fuhe River estuary to Baiyangdian Wetland in Northern China. Chemosphere 2021;280:130800. DOI PubMed

84. Yin L, Wen X, Huang D, et al. Microplastics retention by reeds in freshwater environment. Sci Total Environ 2021;790:148200. DOI PubMed

85. Sun D, Wang J, Xie S, et al. Characterization and spatial distribution of microplastics in two wild captured economic freshwater fish from north and west rivers of Guangdong province. Ecotoxicol Environ Saf 2021;207:111555. DOI PubMed 